日消外会誌 $12(8): 547 \sim 552,1979$ 年

胆道系悪性腫瘍における経動脈門脈造影像の検討

\begin{tabular}{|c|c|c|c|c|c|}
\hline \multicolumn{6}{|c|}{ 筑波大学臨明医学系外科 ${ }^{*}$ 问以科 } \\
\hline 名越 & 和夫 & 折店 & 和雄 & 轟 & 健 \\
\hline 更科 & 広実 & 竹島 & 徹 & 高瀬 & 靖) \\
\hline 尾崎 & 梓 & 深尾 & 立 & 岡村 & \\
\hline *中原 & 朗 & 岩崎 & 洋治 & & \\
\hline
\end{tabular}

\title{
EVAlUATION OF ARTERIAL PORTOGRAPHY IN CARCINOMA OF THE BILIARY TRACT
}

\section{Kazuo NAGOSHI, Kazuo ORII, Takeshi TODOROKI, Hiromi SARASHINA, Toru TAKESHIMA, Yasuhiro TAKASE, Azusa OZAKI, Katashi FUKAO, Takao OKAMURA, *Akira NAKAHARA and Yoji IWASAKI}

Institute of Clinical Medicine, Department of Surgery

* Department of Internal Medicine, the University of Tsukuba

肝門部胆管癌 10 例, 胆のう癌 6 例を対象に術前, 門脈への浸潤の有無を知る目的で, 経動脈門脈造影を 施行し，門脈像と手術および剖検所見との対比より，その診断的意義を検討した．血管抎張剤を用いた経 上晹問膜動脈門脈造影を行えば常に明瞭な門脈造影像を得ることがでさる.さらに門脈と胆管の位置関係 を考慮して門脈を 2 分間（正面，第 2 科位）より撮影し，得られた門脈造影所見は手術および剖検所見々 よく一致し，切除可否の決定の術式選択に有効であった。また胆管造影像で肝内胆管第 2 分岐部を越えて 肝側に浸潤のおよぶ胆管癌では, 門脈への浸潤の可能﨡が高いことが判明した。

索引用嚾：経動脈門脈造影, 経皮経肝門脈造影, 肝門部胆管癌, 胆のら癌, 肝門部胆管空腸吻合術

はじめに

胆道采悪性腫湯のなかでとくに肝門部胆管癌および胆 のう癌は, その早期発見の機会は少なく外科治療の対象 が進行癌であることが多い。したがってその手術成績 る他の消化管悪性腫济に比べ著しく劣るのが現況であ る ${ }^{1) ~ 5)}$. た最近の胆道精查法のめざましい進歩にもか かわらず，腫瘍の浸潤範用の決定や切除可否の決定の客 的観方法に乏しく, 手術時所見より経験的に術式の選択 がなされることが多い．ところでこれら肺門部胆管癌お よび胆のう癌の炀除可否を決定する極めて重大な因子に 門脈への浸潤の有無がある.とくに最近報告をみるよう になったこれら疾患に対する肝葉切除術や血行再建を附 加した拡大肝葉切除術を行らにあたっては, 術前に悪性 腫湟の門脈への浸潤の有無を正しく診断することが不可 決といわねばならない，一方門脈造影法は経脾門脈造影
法，経皮経肝門脈造影法，腹控動脈あるいは上腸間膜動 脈造影法などの方法により行われているが，われわれは これまで動脈造影時に施行できる血管拡張肪を用いた経 上腸間膜動脈造影を行ってきた.

そこで，このよらな方法で得られた門脈像に前述のよ らな診断能があるかどらか知る目的で，われわれの経験 した肝門部胆管癌および胆のう癌症例について門脈像と 胆管像, 門脈像と手術あるいは剖検所見とを比較, 検討 した.

\section{対象および方法}

1976年10月筑波大学病院開設より1979年 1月まで（2 年 4 力月間) 飞経験した21例の胆道系覀性腫場 (Table 1)のなかで, 手術および剖検で病理組織学的に確認さ れた肝門部胆管癌10例，胆のう癌 6 例を対象とした.な お男女比は, 肝門部胆管癌で $4: 6$, 胆の5癌で $3: 3$ 
Table 1 Sex and Age of patients with biliary tract carcinoma

\begin{tabular}{|c|c|c|c|c|c|}
\hline \multirow{2}{*}{ Location } & \multicolumn{2}{|c|}{ Sex } & & \multicolumn{2}{|c|}{ Median Age } \\
\hline & Male & Female & & $(y r)$ & (range) \\
\hline Extrahepatic biliary system & 7 & 8 & 15 & 69.7 & $(19-84)$ \\
\hline Upper region & 5 & 7 & 12 & 58.2 & $(19-81)$ \\
\hline Middle region & 1 & - & 1 & 80.0 & \\
\hline Lower region & 1 & 1 & 2 & 71.0 & $(58-84)$ \\
\hline Gallbladder & 3 & 3 & 6 & 67.8 & $(50-77)$ \\
\hline
\end{tabular}

であり，年龄は19歳から81歳（平均60.8歳）である.

門脈像は，Seldinger 法による動脈造影検查時に得ら れる，腹腔動脈造影静脈相および血管払張昘を用いた経 上腸間膜動脈門脈造影法によった，通常腹腔動脈造影は $40 \mathrm{ml}$ の造影剂 (Iodamide Meglumin,コンラキンンH) を $10 \mathrm{ml} / \mathrm{sec}$ で注入し，撮影のプログラムは最初の 8 枚 を秒間 2 枚，次の 4 枚を秒間 1 枚，最後の 4 枚を 2 秒 間に 1 枚の計16枚で行った. また経上腸間膜動脈門脈 造影は，上腸間膜動脈に挿入しカテーテルより血管払張 剂（塩酸パパベリン $40 \mathrm{mg}$ ）を注入し，引き続いて造影 阂 $50 \mathrm{ml}$ を $12.5 \mathrm{ml} / \mathrm{sec}$ で注入し，撮影は最初の 8 枚を秒 間 1 枚で，次の 8 枚を 2 秒間に 1 枚の計16枚ので行なっ た。な执わわれは，門脈への浸潤の有無を正しく診断 するためには，2 万向より門脈像を得る必要があると考 えた。このため背臥位門脈正面像は腹腔動脈造影法で, 背臥位第 2 斜位 $30^{\circ}$ 像は経上腸間膜動脈門脈造影法で撮 影した. 胆管造影像は主に P.T.C 像により読影し, 少 数例に ERC，DICを用いた。 な扣手術掞よび剖検所見 は，血管造影時より 3 力月以内の症例のみを対象とし た。

\section{成 縝}

血管㧒張剂を用いた経上腸間膜動脈門脈造影では, 1 例を除く他の全症例に診断的に有効な門脈像を得ること ができた（Fig.1).不充分な造影に終った1例は大動脈 の強い蛇行のために，上腸間膜動脈に Catheterization L たカテーテルが造影剤注入時の王力によって, recoil し 充分量の造影剂が上腸間膜動脈内に注入されなかった症 例である.これらのことより血管拡張剤に引きつついて 充分量の造影斑を上腸間膜動脈に注入することにより， 常に診断的に有効な門脈像を得ることが可能であると考 之る.

しかし腹腔動脈造影静脈相で同様な診断的に有効な門 脈像を得た症例は2/15と少なく(Table 2)，(Fig.2) 症 例によっては背臥位で経上腸間膜動脈門脈造影を追加し
Fig. 1 Normal superior mesenteric arterial portography of the patient with lower bile duct carcinoma. The superior mesenteric vein, portal vein and intrahepatic potal vein are clearly visualized after injecting $40 \mathrm{mg}$ of papaverin and $50 \mathrm{ml}$ contrast medium into the superior mesenteric artery.

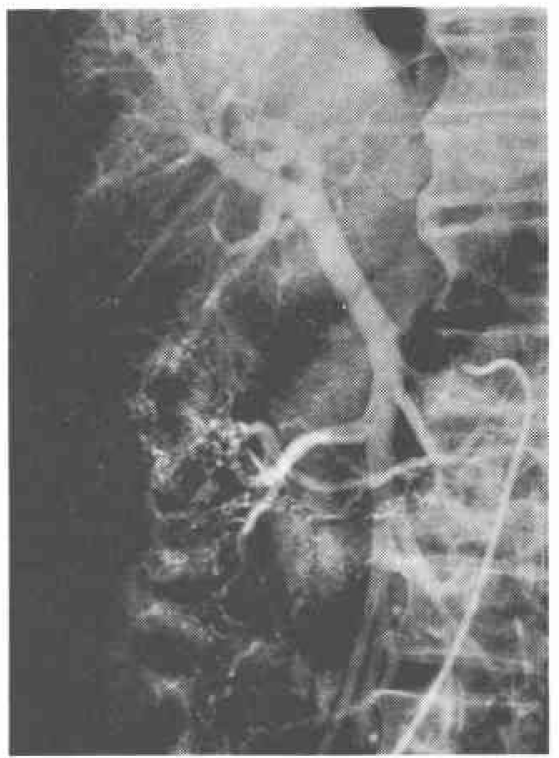

Table 2 Evaluation of celiac and superior mesenteric portography

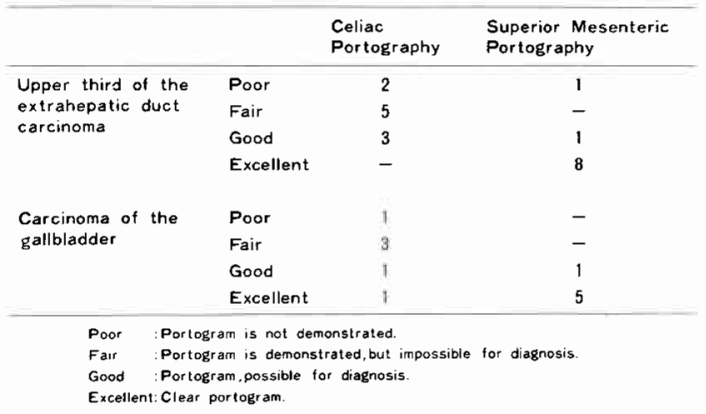

た. 腹空動脈造影静脈相で明瞭な門脈像を得ることが困 難なのは注入された造影剤が大量に脾葴に pool された のち，徐々に門脈系へと移行するため，門脈血中の造影 剂濃度が，経上腸間膜動脈門脈造影に比べ薄いためであ ると考えられる.

ところで肝門部胆管癌の 手術々式は, 胆管切除術と 肝切除兼切除術に大別することができるが，われわ れは次のような基準により手術々式の選択を行ってい

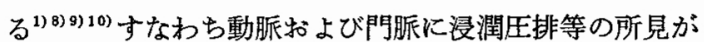


Fig. 2 Venous phase of celiac angiography in the same patient as Fig. 1. Portogram is demonstrated, but impossible for diagnosis.

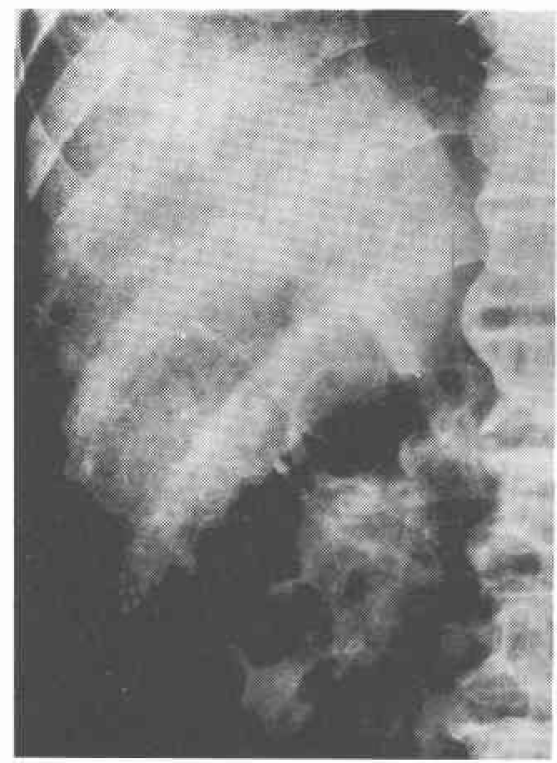

なく，胆管像でも肝内胆管の第 2 分岐部を越えて浸潤 所見のない症例には，肝門部胆管切除術を予定する．ま た右葉あるい性葉の一側葉の血管系に浸潤，王排など の所見を認めるか，あるいは一側葉の胆管の第 2 分岐を 越光て浸潤所見をみる症例には肝切除兼胆管切除術を予 定術式としている.さららよりよい根治性を得るために は，尾状葉からの肝管が左右肝管合流部に極めて近接し て流入してくることを考慮すれば肝門部原発の胆管癌の 多くの症例に，肝葉切除が適応となると考克る，このよ

Table 3 Correlation between cholangiography and portography

\begin{tabular}{|c|c|c|c|}
\hline & Case & Cholangiography & Portography \\
\hline \multirow{2}{*}{ 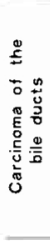 } & $\begin{array}{l}1 \\
2 \\
3 \\
4\end{array}$ & $\begin{array}{l}\text { Tumors below the second } \\
\text { bifurcation of the hepatic } \\
\text { ducts }\end{array}$ & Normal portography \\
\hline & $\begin{array}{c}5 \\
6 \\
7 \\
8 \\
9 \\
10\end{array}$ & $\begin{array}{l}\text { Tumors beyond the scond } \\
\text { bifurcation of the hepatic } \\
\text { ducts }\end{array}$ & $\begin{array}{l}\text { Irregular cariber nearby } \\
\text { bifurcation of the portal } \\
\text { vein or its hepatic branch }\end{array}$ \\
\hline \multirow{5}{*}{ 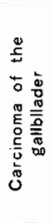 } & 1 & & \\
\hline & 2 & Ir regular cariver of the & \\
\hline & $\begin{array}{l}3 \\
4\end{array}$ & extrahepatic bile ducts & $\begin{array}{l}\text { Ir regular cariber and defor- } \\
\text { mity of the portal vein }\end{array}$ \\
\hline & 5 & $\begin{array}{l}\text { Complete obstruction of the } \\
\text { extrahepatic bile ducts } \\
\text { below the bifurcation }\end{array}$ & \\
\hline & 6 & $\begin{array}{l}\text { Displacement of the extrah- } \\
\text { epatic bile ducts }\end{array}$ & $\begin{array}{l}\text { Smooth displacement of the } \\
\text { portal vein }\end{array}$ \\
\hline
\end{tabular}

Fig. 3-a Superior mesenteric arterial portography of the patient with carcinoma beyond the second bifurcation of the hepatic ducts. Irregular carber is demonstrared in the portal bifurcation $(\square)$.

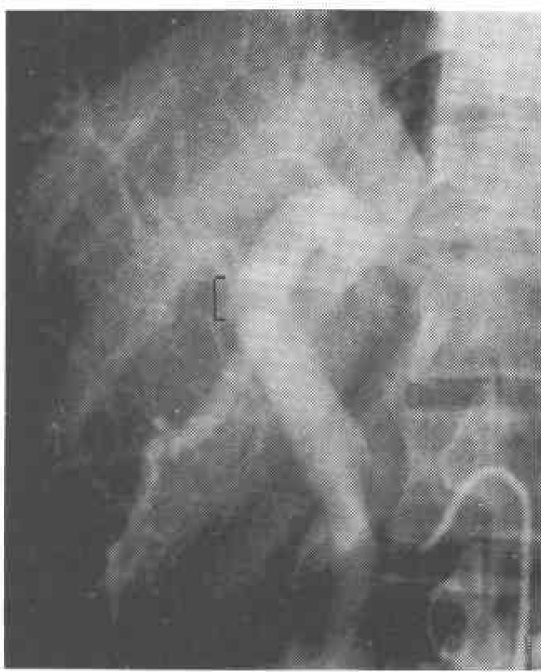

Fig. 3-b Superior mesenteric arterial portography in the same patient as Fig. 3-a. Irregular cariber can not be recognized by a routine projection.

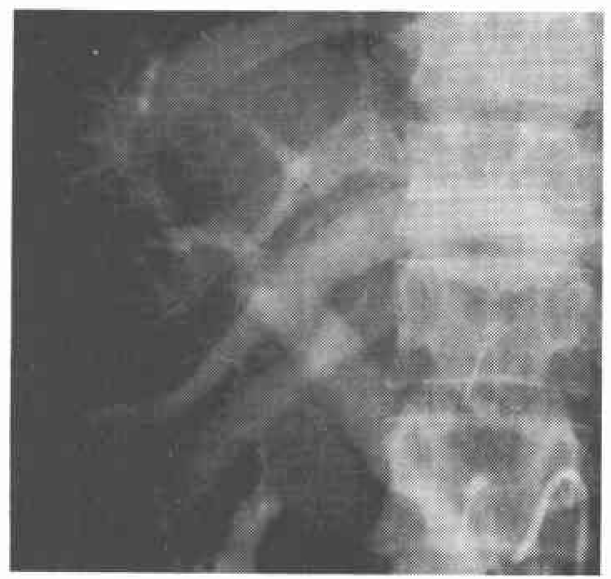

らに胆管像よりみた術式選択の基準を肝内胆管第 2 分岐 としているため，癌浸潤が肝内胆管第 2 分技部を越えて 肝側へと浸潤する症例と，そうでない症例に分けて，門 脈像と胆管像，門脈像と手術あるいは剖検所見とを比較 した.

胆管造影像よりみた窑浸潤籍囲と門脈造影像の比較

䀒門部胆管癌10例中 (Table 3), 肝内胆管第 2 分岐部 を越えて浸潤のおよぶ 6 症例 $(5,6,7,8,9 ， 10)$ では，症例 5 を除く $5 / 6$ に肝門部周辺門脈に圧排，浸潤 
Fig. 4 Superior mesenteric arterial portography of the patient with carcinoma below the second bifurcation of the hepatic duct. Portal and intrahepatic vein are normal.

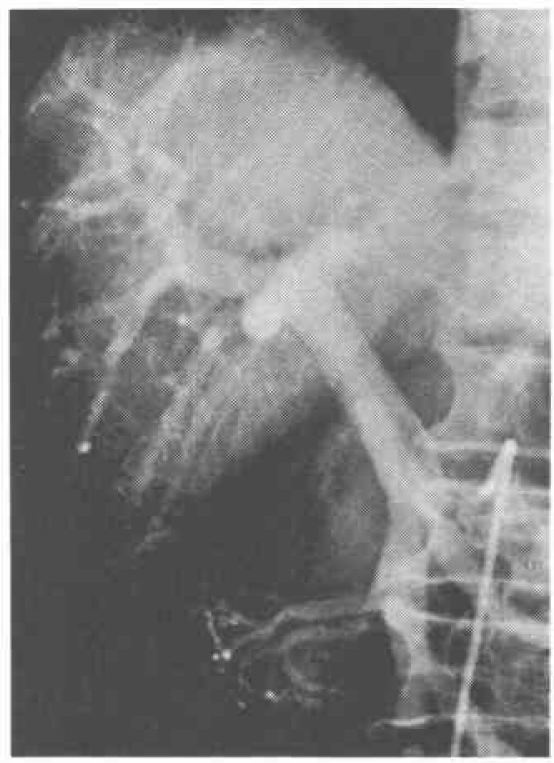

所見 (Fig. 3) を認めた。比較的限局型の 4 症例 (1, $2 ， 3 ， 4)$ では同所に異常所見をみたるのはなかった (Fig. 4).

さらに 6 例の胆のら癌の胆管像と門脈像を比較する (Table 3) と，胆管の完全閉塞を呈したものは症例 5 の みで他の 4 症例 $(1 ， 2 ， 3 ， 4)$ はすべて総肝管に狭 窄を伴う浸潤像を呈した. これら6 症例の門脈像を検討

Fig. 5-a Venous phase of celiac angiography of the patient with carcinoma of the gallbladder. The portal vein has irregular cariber.

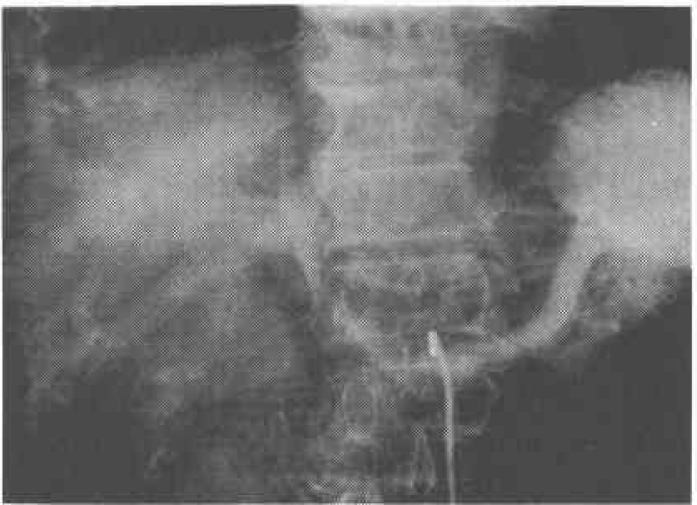

すると，5例に門脈本幹の圧排，浸潤所見 (Fig. 5)を， 他の 1 例にsmoothな圧排所見 (Fig. 6) をみた。なお䏣 のう癌による排，浸潤所見を読影するにあたっては， 背臥位門脈正面像より，第 2 斜位 $30^{\circ}$ 門脈像 がより 所見 が強調され読影が容易であった (Fig.5 a, b).

Fig. 5-b Superior mesenteric arterial portography in the some patient as Fig. 5-a. Irregularity of the portal vein is exaggerated by a left oblique $30^{\circ}$ projection.

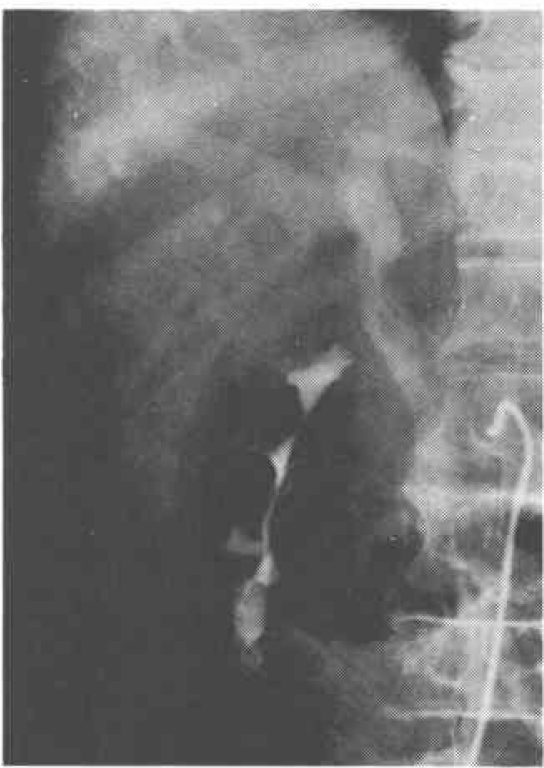

Table 4 Correlation between portography and local appearance at surgery or autopsy

\begin{tabular}{|c|c|c|c|}
\hline & Case & Portography & Local Appearance of the Tumor \\
\hline \multirow{10}{*}{ 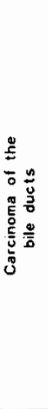 } & 1 & & \\
\hline & 2 & & No infiltration to the \\
\hline & $\frac{3}{4}$ & Normal Portography & Portal vein \\
\hline & 3 & & \\
\hline & 6 & $\begin{array}{l}\text { Narrowing at the right } \\
\text { principal branch }\end{array}$ & $\begin{array}{l}\text { Slight infiltration to the } \\
\text { right principal portal branch }\end{array}$ \\
\hline & 7 & $\begin{array}{l}\text { Narrowing below the } \\
\text { bifurcation and no } \\
\text { visualization of left } \\
\text { portal branch }\end{array}$ & $\begin{array}{l}\text { Intiltration to the bifurcation } \\
\text { and left principal portal branch }\end{array}$ \\
\hline & 8 & & Infiltration to the bifurcation \\
\hline & & Narrowing below the & \\
\hline & 9 & $\begin{array}{l}\text { bifurcation and right } \\
\text { principal branch }\end{array}$ & Same with the above \\
\hline & 10 & $\begin{array}{l}\text { Narrowing of the left } \\
\text { Drincidal branch }\end{array}$ & $\begin{array}{l}\text { Infiltration to the left } \\
\text { principal portal branch }\end{array}$ \\
\hline \multirow{5}{*}{ 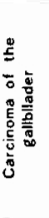 } & 1 & & \\
\hline & $\begin{array}{l}2 \\
3\end{array}$ & Irregular cariber and & surrounding portal and superior \\
\hline & 4 & $\begin{array}{l}\text { detormity of the } \\
\text { portal vein }\end{array}$ & mesenteric vern \\
\hline & 5 & & $\begin{array}{l}\text { Direct infiltration to the } \\
\text { portal vein and lymphnodes } \\
\text { metastasis }\end{array}$ \\
\hline & 6 & Smooth displacement & $\begin{array}{l}\text { No metastasis to the lymphnodes } \\
\text { and no direct infiltration to the } \\
\text { Dortal vein }\end{array}$ \\
\hline
\end{tabular}


Fig. 6-a Superior mesenteric arterial portography of the patient with carcinoma of the gallbladder. The portal vein is displace to the left, but its cariber is smooth.

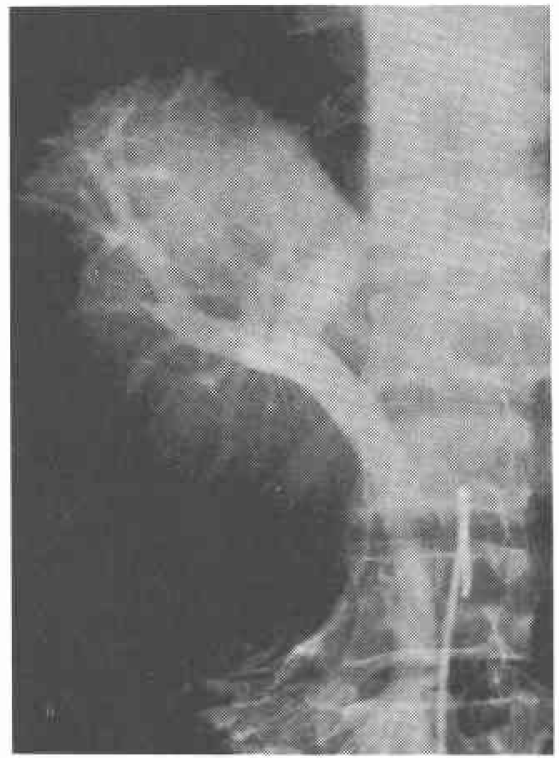

Fig. 6-b Venous phase of celiac angiography in the same patient as Fig. 6-a. The portal vein is displaced to the left and its right margin is not clearly visualized because of the stream line phenomenon.

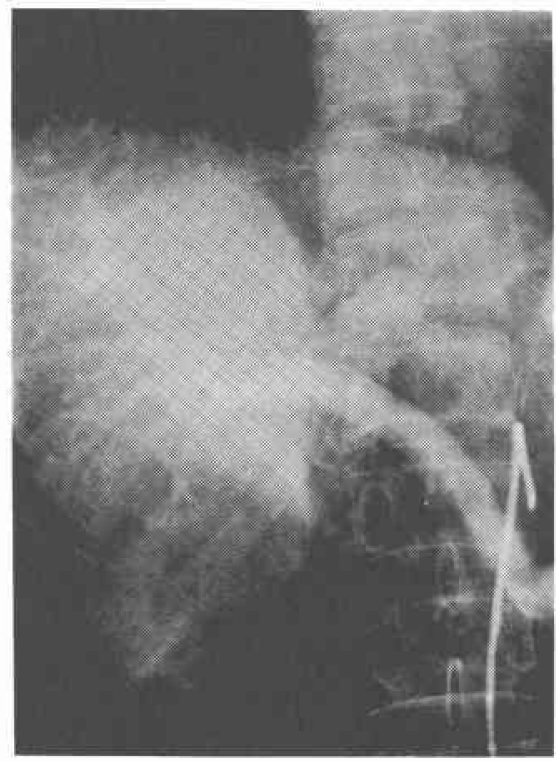

\section{手術または剖検所見と門脈造影像の比較}

門脈造影像と手術または剖検による膵後部肝十二指 腸靶帯から肝門部に 至る 局所の所見を比較検討する

(Table 4) と, 肝門部胆管癌で病変部に接する門脈に 浸潤ありと診断した 4 例全例に術中または部検所見で漫 潤を認めた。 また門脈像で同所に浸潤所見のみられなか った 5 例には，いずれも門脈に浸潤はなかった。

なお胆のら癌の 6 例中，浸潤圧排所見ありとした 5 例 の全例に胆のう癌の肝十二指腸靱帯への直接浸潤，ある いは著明な肝十二指腸靬带, 膵上縁, 膆後部へのリンパ 節転移をみた． smoothな圧排所見のみ（Fig.6)で浸潤 なしと診断した 1 症例では，緊満した胆のらによる肝十 二指腸勒帯の圧排のみで漫潤はなく，抎大肝葉切除術に より根治術が可能であった.

\section{考察}

胆道系悪性腫瘍の中でも外科治療の困難な肝門部胆管 㿋および胆のう癌の切除可否の決定や術式選択のために は，術前に門脈への浸潤の有無を正確に知る目的で明瞭 な門脈造影像を得ることが重要である。

門脈造影法は，1945年 Blakemore らにより開腹下に 門脈系に直接カテーテルを㨉入し，施行された. その 後 Child, Moore, Rousselot らにより同法が追試された が，その手技が煩雑で満足な結果を得ることは困難であ った.なおこの検查法の最大の欠点は開腹を要するため に，手術中に行われ術前診断に用いることができないこ とであろう. ついで1951年 Abeatini らが犬での経脾門 脈造影を報告し，Legen が人にこれを応用し門脈造 影像を得ることに成功した 影は一部の施設で行われているが，後出血などの重大な 合併症が多く通常は手術直前に行われることが多い：そ れゆ最近では Ödman ${ }^{12)}$ らによって報告された動脈造 影の際の Arterial Portography で代用することが多くな っている. また Lunderquist らによって始められた経皮 経肝門脈造影法 $\left.{ }^{13)}{ }^{14}\right)$ は, 経脾門脈造影法に比較して合併 症は少ないが, 後出血, hemobilia などの合併症の報告 をみる，さらにその手法は必ずしも容易ではなく，成功 率も報告者によってさまざまであり，造影診断の目的で 同法を行 万には demerit も考慮しなければならない。 しかし，われわれが通常行っている血管桩張剂を用いる 経上腸間膜動脈門脈造影法は動脈造影検査時に，全く特 殊な手技を必要とせずに明瞭な門脈像を得ることができ る利点がある.さて経動脈門脈造影法のために用いられ る血管抎張㓮としては，パパベリン，プロスタグランデ 
ィン,イミダリンなどがあるが，われわれは，安価で入 手の容易な，血管壁平滑筋作動性のパパベリンを用い ている．また肝膵疾患451例（肝硬変376膵75）の経験で は，注入時に灼熱感がある以外は同薬剤によって合併症 をみたるのは 1 例むなく，きわめて安全な検査法であ るといえる。なお腹腔動脈造影静脈相による門脈像は Table 2 に示すごとく，診断的に有効な門脈像が得られ ることは少ない，脾動脈造影あるいは上腸間膜動脈門脈 造影を行うことより明瞭な門脈像を得ることが可能とな $3^{1115) 16)}$ ．われわれは脾動脈造影よりは，脾の大きさに 左右されることなく常に明瞭な門脈像を得ることができ る経上腸間膜動脈門脈造影法を頻用している。

門脈への浸潤の有無を正しく診断するためには，すで に述べたように 1 方向だけでなく 2 方向より門脈を撮影 する必要がある．胆管と門脈との解剖学的位置関係 よ $\eta^{17)}$ ，背臥位のみで門脈への浸潤，圧排の有無を正し く診断することは困難である。このため第 2 斜位 $30^{\circ}$ に より門哌造影を行えば，上腸膜静脈，門脈が椎体の右側 に，ほぼ一值線に造影され肝門部，脺上縁，嗒後部，お 上び肝十二指腸靬帯内のりンパ節転移に上る影響も読影 が容易となる (Fig. 5). しかし Lumbar lordosis の症例 では門脈系が大きく変形し，走行異常をきたすので読影 に際して，十分な注意が必要であるう.

ところでわれわれの行っているArterial Portography による門脈造影所見と手術あるいは剖検の結果を対比す ると，閭脈像で浸潤ありと診断した症例のすべてに，レ 線像に一致した浸潤圧排所見をみた。

また胆管像で第 2 分岥部を越点て浸潤ありと診断した 症例の $5 / 6$ に門脈への浸潤をみた。

これらのことより動脈造影検査時に，血管拡張剤を用

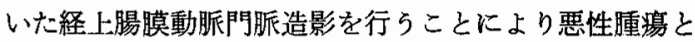
閒脈との関係を術前に正確に知ることが可能となると考 える.

\section{むすび}

1）動脈造影検查時に同時に施行できる血管㧪張剤を 用いた経上腸間膜動脈門脈造影により，安全かつ容易 飞，常に明膫な門脈造影像を得ることができる.

2）このようにして得られた門脈像は，手術ならびに 剖検所見とよく一致し，正確な術前診断が可能となる.

3）肝門部胆管癌で肝内胆管第 2 分岥部を越えて浸潤 のおよぶ症例では，門脈浸潤の可能性が高い。

4）胆道系悪性腫塲に対して経上晹門膜動脈門脈造影 を2方向より撮影することにより原発部位だけでなく，
周团へのリンパ節転移による門脈系への浸潤，圧排の有 無が診断可能となる.

\section{文献}

1）岩崎洋治隹か：肝門部胆管癌切除術一特に左葉 切除を伴つた肝門部胆管癌切除術一. 日外誌, 79 : 788-791, 1978.

2) Longmire, W.P. Jr., et al.: Carcinoma of the extrahepatic biliary tract. Ann. Surg., 178: 333-345, 1973.

3）木南義男㳗か：肝門部胆管癌の手術成績と型分 類. 日消外誌, $11 ： 379-383,1978$.

4) Todoroki, et al.: Gross Appearance of Main Hepatic Duct Carcinoma and Its Prognosis. (A collective Review of 23 Successful Resections.) Surg. Gynecol. Obstet. in press.

5）土屋○一ほか：外科から 久た胆道癌。胃と腸， $12: 733-743,1977$.

6) 大藤正雄ほか：胆のう癌と胆管癌，早期発見の 可能性. Medicina, 13：212-213，1976.

7) Richard, P.F., et al.: Primary carcinoma of the gallbladder. Study of 108 cases. Canada J. Surg., 19: 27-32, 1976.

8) 岩崎洋治 ほ か：肝門部胆管癌に対する手術々 式. 手術, 30：795-803，1976.

9）岡村隆夫ほか：肝門部胆管癌の治療一とくに切 除例を中心にして一. 外科, $38: 867-873$, 1976.

10) Iwasaki, et al.: Treatment of carcinoma of the biliary system. Surg. Gynecol. Obstet., 144: 219-224, 1977.

11) Abrams, H.L.: Angiography.: 1073-1088, Little, Brown and Company, Boston, 1971.

12) Odman, P.: Percutaneous Selective Angiography of the Coeliac artery. Acta Radiol., I, 1958.

13) Lunderquist, A.: Transhepatic catheterization and obliteration of the coronary vein in patients with portal hypertension and esophageal varices. New Eng. J. Med., 291. $649-652,1974$.

14）鈴木光二注か：経皮経肝的門脈造影法につい て. 第 1 報：方法と䛦断的意義について. 䀒臓, $609-617,1976$.

15）有山襄ほか：膵癌の診断一血管造影一。内 科, $26: 407-415,1975$.

16) Reuter, S.R. and Redman, H.C.: Gastrointestinal angiography: 269-283, Saunders, Philadelphia, 1972.

17) Hoevels, J.: Topographic relation of portal vein to extrahepatic bile ducts. A combined portographi-cholangiographic study in 25 cadavers. Fortschr. Röntgenstr., 129: 217222, 1978. 